\title{
KINERJA BADAN KESWADAYAAN MASYARAKAT (BKM) \\ DALAM PENGAWASAN PENGGUNAAN DAN \\ PENGELOLAAN DANA P2KP \\ DI KECAMATAN ADIWERNA KABUPATEN TEGAL
}

\author{
Puji Rahayu ${ }^{1}$
}

\begin{abstract}
Abstrak
Penelitian ini bertujuan untuk mengetahui kinerja Badan Keswadayaan Masyarakat (BKM) dalam pengawasan penggunaan dan pengelolaan dana BLM (Bantuan Langsung Mandiri) ekonomi bergulir P2KP di Kecamatan Adiwerna Kabupaten Tegal. Penelitian difokuskan pada kinerja BKM khususnya di bidang ekonomi yaitu pemberian modal usaha kepada Kelompok Swadaya Masyarakat (KSM) terutama pada Program Penanggulangan Kemiskinan di Perkotaan P2KP tahap kedua di Kecamatan Adiwerna Kabupaten Tegal, banyak program penanggulangan kemiskinan yang dilakukan pemerintah, dan belajar dari pengalaman terdahulu di P2KP tahap pertama kurang efektif, diharapkan ada proses belajar dari masa lalu dalam hal perbaikan kinerja.

Metode yang digunakan dalam penelitian ini adalah kualitatif deskriptif dengan strategi interpretative practice (pemahaman) yang menguak dan memberikan gambaran sebenar-benarnya tentang kinerja Badan Keswadayaan Masyarakat (BKM) terhadap pengawasan penggunaan dan pengelolaan dana P2KP di Kecamatan Adiwerna Kabupaten Tegal. Subyek penelitian ditentukan menggunakan teknik purposive yaitu Anggota BKM, anggota UPK dan anggota KSM. Sumber data yang digunakan adalah catatan wawancara, hasil pengamatan penulis, dan dokumen-dokumen penting BKM. Teknik pengumpulan data yang digunakan adalah observasi, wawancara dan dokumentasi. Untuk mengecek validitas data digunakan teknik triangulasi. Data dianalisis menggunakan teknik analisis data model interaktif.

Hasil dari penelitian ini adalah kinerja BKM dalam kelembagaan yang belum efektif, karena (1) belum adanya kerjasama antar anggota BKM disebabkan karena lemahnya pemahaman pengurus BKM mengenai fungsi dan peran mereka sebagai agen perubah dan pemberdayaan masyarakat, (2) belum ada kerjasama antara anggota BKM dengan kelompok masyarakat, (3) belum ada kerjasama antara kelompok masyarakat ataupun BKM dengan masyarakat ataupun pihak luar. Selain itu adanya kredit macet sangat besar karena kurang inisiatif dan kreatif dari dalam diri BKM itu sendiri dalam hal pengawasan dana P2KP baik itu dalam hal sosialisasi kepada KSM, penyaluran dana sehingga banyak yang tidak tepat sasaran dan ditemukan penyalahgunaan dana BLM dan BOP BKM, banyak faktor tersendat di Ketua KSM ataupun dari anggota KSM.
\end{abstract}

\footnotetext{
${ }^{1}$ Penulis adalah alumni Program Studi Pendidikan Sosiologi, FISE, Universitas Negeri Yogyakarta
} 
Kata Kunci: Badan Keswadayaan Masyarakat, Penanggulangan Kemiskinan, Kinerja

\section{A. Pendahuluan}

Kemiskinan di perkotaan merupakan masalah laten dan kompleks, karena implikasi sosial dan budayanya tidak hanya melibatkan dan mewujudkan berbagai masalah sosial yang ada di kota yang bersangkutan saja atau hanya menjadi masalah bagi orang miskin di kota tersebut, tetapi juga melibatkan masalah-masalah yang ada di pedesaan dan di kota-kota lain yang melibatkan juga golongangolongan sosial lainnya yang ada di perkotaan baik itu langsung maupun tidak langsung. Masalah kemiskinan di perkotaan menjadi penting karena kedudukan kota-kota dalam masyarakat tersusun dalam suatu jaringan yang bertingkat-tingkat dan merupakan pusat-pusat penguasaan atau pendominasian bagi pengaturan kesejahteraan kehidupan masyarakat. Sistem pendominasian tersebut bukan hanya melibatkan aspek-aspek ekonomi, tetapi juga aspek sosial, aspek komunikasi dan aspek kebudayaan. $^{2}$

Kebijaksanaan pembangunan ekonomi yang diambil oleh pemerintah dapat dikatakan kurang berhasil dalam mengurangi angka kemiskinan dan kesenjangan sosial ini. Kebijaksanaan pembangunan yang selama ini dilaksanakan hanya mementingkan pertumbuhan ekonomi yang tinggi dan

\footnotetext{
2 Parsudi Suparlan, Kemiskinan di Perkotaan. Jakarta: Yayasan Obor Indonesia, 1993, hlm. xv dan xvi.
}

mengesampingkan aspek pemerataan. Menurut kebijaksaan tersebut dengan pertumbuhan ekonomi yang tinggi berarti dapat mengurangi kesenjangan sosial dan juga terjadi penyerapan tenaga kerja yang besar sehingga angka pengangguran dapat berkurang. Pertumbuhan ekonomi yang tinggi juga dijadikan indikator bahwa kesejahteraan sosial masyarakat mengalami peningkatan. Tetapi dalam masyarakat yang terjadi justru sebaliknya, dimana kemiskinan, pengangguran dan kesenjangan sosial justru semakin tinggi. Pertumbuhan ekonomi yang tinggi karena adanya perputaran uang yang sangat cepat sehingga mengakibatkan inflasi yang tinggi, karena inflasi itulah harga semakin mahal. walaupun pendapatan semakin tinggi atau naik dengan harga sembako yang juga naik, bisa dikatakan tidak terjadi kesejahteraan atau sama saja. Yang terjadi malah yang kaya semakin kaya dan yang miskin semakin miskin.

Untuk itu sudah saatnya paradigma pembangunan yang berorientasi pada pertumbuhan yang menempatkan kapital finansial dan kapital fisik sebagai modal utama pembangunan, digantikan dengan paradigma pembangunan yang berpusat pada pemberdayaan masyarakat dan lebih mengutamakan perhatiannya pada masyarakat ekonomi lemah. Pembangunan cara ini hanya akan dapat diwujudkan kalau pembangunan mampu 
meningkatkan partisipasi masyarakat dalam proses pembangunan. Dengan banyak alternatif program-program yang diberikan oleh pemerintah baik itu bantuan modal ataupun bantuan lain dengan tujuan untuk mensejahterakan rakyatnya, tetapi bila masyarakat tidak mempergunakan program atau bantuan tersebut dengan efektif atau bisa dikatakan tidak ada kepedulian atau partisipasi rakyat itu sendiri maka program yang diberikan pemerintah tidak berarti sama sekali.

Pemerintah dalam usaha untuk mengentaskan kemiskinan ini telah mengeluarkan beberapa strategi pembangunan dari proyek inpres sampai program pengembangan kelembagaan, kemudian tahun 1998 pemerintah mengeluarkan kebijaksanaan JPS (Jaring Pengaman Sosial) untuk meringankan dampak krisis moneter yang masih berlangsung hingga sekarang. Pada perkembangannya, untuk mendukung program JPS ini pemerintah juga membuat suatu program kebijakan yang diarahkan khusus untuk pemberdayaan masyarakat miskin di perkotaan yaitu Program Penanggulangan Kemiskinan di Perkotaan (P2KP). Program ini pertama kali dilaksanakan pada tahun 1999/2000 dan tahap kedua dilaksanakan 2003/2004 dan tahap ketiga di P2KP PNPM.

Program P2KP adalah merupakan program untuk penanggulangan kemiskinan di perkotaan yang menekankan pada aspek pemberdayaan masyarakat itu sendiri. Dalam pelaksanaan program P2KP tersebut di tingkat kelurahan dibentuk Badan Keswadayaan Masyarakat (BKM) yang bertindak sebagai lembaga yang memfasilitasi peran serta partisipasi yang tumbuh dari bawah. Dalam program ini masyarakat miskin di perkotaan dapat berpartisipasi secara aktif dengan membentuk Kelompok Kelompok Swadaya Masyarakat (KSM) kemudian membuat proposal pencairan dana untuk kegiatan yang mereka rencanakan melalui perantara UPK (Unit Pengelola Keuangan), setelah mendapat persetujuan dari BKM maka pencairan dana bagi pelaksanaan kegiatan masyarakat yang diusulkan tersebut dapat segera dicairkan, yaitu dengan ketentuan untuk kegiatan dalam pembangunan.

Masyarakat harus mengembalikan dana pinjaman tersebut dengan cara mengangsur dengan tata cara yang telah disepakati. Sehingga penggunaan dana pinjaman tersebut haruslah bersifat produktif dan menghasilkan agar keberadaan dana tersebut terus mengalir dan tidak mengalami kemacetan seperti program-program pemerintah yang sudah-sudah.

Kecamatan Adiwerna yang terdiri dari 21 desa, diantaranya 3 desa sudah melaksanakan program P2KP tahap 1 (satu), lima desa mendapatkan kesempatan di P2KP tahap 2 (dua), sedang 13 desa lainnya baru mendapatkan program P2KP tahap 3 (tiga) atau yang sekarang disebut PNPM P2KP. Pada pelaksanaan P2KP Tahap 1 ternyata masyarakat miskin perkotaan justru tidak dapat mengakses dana pinjaman tersebut. Dikarenakan harus mengembalikan atau mengangsur dana pinjaman tersebut. 
Akibatnya dana tersebut justru digunakan dan dimanfaatkan oleh masyarakat menengah ke atas karena secara logika mampu mengembalikan dana pinjaman yang bersifat produktif tersebut. Bahkan keberadaan dana tersebut di beberapa daerah dijadikan sebagai lahan empuk untuk bisa meminjam uang yang dikembalikan secara berangsur oleh sejumlah masyarakat menurut kriteria pelaksanaan P2KP sudah sangat menyimpang yaitu digunakan hanya sekedar untuk kebutuhan konsumtif dari warga masyarakatnya. Akibatnya target P2KP tidak sesuai dengan yang diharapkan, namun hal ini menjadi hal yang belum jelas apakah P2KP mengerti akan banyaknya hal-hal semacam ini terjadi di lapangan.

Kenyataan di lapangan yang tidak sesuai dengan harapan ini juga sebenarnya diketahui BKM. Namun BKM mengabaikan dan tetap memberikan izin guna pencairan dan pelaksanaan program P2KP karena tuntutan program P2KP tersebut yaitu dana yang dikelola UPK harus terus berputar atau dengan kata lain peminjam harus dapat mengembalikan pinjaman tersebut.sehingga pada akhirnya yang meminjam dan memanfaatkan dana P2KP tersebut adalah orangorang yang tergolong mampu (anggapan bisa mengembalikan pinjaman dana), sehingga masyarakat tidak mampu atau yang tidak dapat mengembalikan pinjamnan akhirnya tidak mendapat pinjaman dan terkesan dikesampingkan. Banyak pihak yang mengerti akan hal-hal yang tidak seharusnya terjadi tersebut, namun ada yang pura-pura tidak tahu, ada yang tahu tapi diam saja atau tidak bisa berbuat apa-apa.

Ketidak

berhasilan

Pengentasan kemiskinan perkotaan melalui BKM tersebut tidak sematamata karena efektif atau tidaknya program pengentasan kemiskinan, tetapi ada semacam budaya kemiskinan yang membuat kemiskinan ini tidak dapat diatasi. Kebudayaan-kebudayaan yang mereka punyai seperti selalu mengharapkan bantuan dan sedekah, menerima nasib, penyimpangan dan penggunaan dana bantuan dan lainnya. Meskipun sebenarnya cara ini adalah cara yang cerdik dan pandai sebagai bentuk adaptasi dalam menyikapi kemiskinan yang mereka hadapi, namun hal inilah yang mengakibatkan munculnya masalah sosial baru sehingga kemiskinan yang terjadi cenderung terus ada.

Mengingat banyaknya persoalan yang muncul dalam pelaksanaan $\mathrm{P} 2 \mathrm{KP}$, maka penulis tertarik meneliti kegiatan-kegiatan BKM dalam usaha mensukseskan P2KP tahap 2 (dua) dengan judul "Kinerja Badan Keswadayaan Masyarakat (BKM) Dalam Pengawasan Penggunaan dan Pengelolaan Dana P2KP Di Kecamatan Adiwerna Kabupaten Tegal".

\section{B. Kajian Pustaka}

1. Pemberdayaan Kelembagaan Dalam Masyarakat

Lembaga-lembaga

kemasyarakatan terdapat di dalam setiap masyarakat tanpa mempedulikan apakah masyarakat 
tersebut mempunyai taraf kebudayaan sederhana atau modern. Hal ini disebabkan karena setiap masyarakat tentu mempunyai kebutuhan-kebutuhan pokok yang apabila dikelompok-kelompokkan terhimpun menjadi lembaga kemasyarakatan.

Istilah

kemasyarakatan

lembaga merupakan terjemahan dari bahasa asing "socialinstitution", karena pengertian lembaga lebih menunjuk pada suatu bentuk sekaligus juga pengertianpengertian yang abstrak perihal adanya norma-norma dan peraturanperaturan tertentu yang menjadi ciri dari pada lembaga atau instansi tersebut. ${ }^{3}$ Berkaitan dengan lembaga yang terdapat di masyarakat dan masyarakat itu sendiri, teori-teori yang mendasarkan diri pada sudut pendekatan tersebut adalah teori Fungsional Struktural, yang memandang masyarakat sebagai suatu sistem sosial yang terdiri atas bagian-bagian atau elemen yang saling berkaitan dan saling menyatu dalam keseimbangan. Asumsi dasar dari teori ini adalah bahwa setiap struktur dalam sistem sosial, fungsional terhadap yang lain. Sebaliknya kalau tidak fungsional maka sruktur itu tidak akan ada atau hilang dengan sendirinya. ${ }^{4}$

Salah satu faktor penyebab kurang berhasilnya upaya pemberdayaan masyarakat miskin adalah karena lemahnya kemampuan

3 Soerjono Soekanto, Teori Sosiologi tentang Pribadi dalam Masyarakat. Jakarta: Ghalia Indonesia, 1982, hlm.191.

${ }^{4}$ George Ritzer dalam Alimadan, Sosiologi Ilmu Pengetahuan Berparadigma Ganda. Jakarta: Rajawali Pers,1992, hlm.25. kelembagaan yang ada dalam masyarakat ini. Kelemahan ini mengakibatkan lembaga atau institusi yang ada, tidak dapat menjalankan perannya dengan baik dalam penyelenggaraan pembangunan di tingkat lokal. Sedangkan untuk dapat memberdayakan masyarakat miskin sangat memerlukan dukungan dan peran aktif dari lembaga atau institusi yang ada dalam masyarakat tersebut agar upaya pemberdayaan masyarakat miskin ini dapat berjalan dengan baik. Peran lembaga yang dimaksud dalam penelitian ini menunjuk pada fungsi lembaga dalam kehidupan bermasyarakat termasuk fungsinya dalam membantu dan mendukung proses pembangunan. Seperti yang dikemukakan Soekanto, bahwa peran itu lebih banyak menunjuk pada fungsi, penyesuaian diri dan sebagai suatu proses. ${ }^{5}$

Pemberdayaan masyarakat ini dapat diwujudkan dengan mengambil langkah-langkah strategi yang langsung memperluas akses rakyat pada sumberdaya yang ada dan menciptakan peluang yang seluas luasnya bagi masyarakat lapisan bawah untuk berpartisipasi dalam proses pembangunan. Dengan cara ini maka mereka akan tanggap dan kritis terhadap segala hal yang menyangkut kehidupannya, serta makin berperan aktif dalam menentukan nasibnya.

Sorikin meramalkan bahwa akan terjadi krisis sistem inderawi dimana beliau mengemukakan begitu mentalitas budaya inderawi

${ }^{5}$ Soerjono Soekanto, op.cit., hlm. 238. 
terbuka dan berkembang, secara bertahap dia memporakporandakan konsensus intelektual dan moral yang merupakan dasar solidaritas sosial yang asasi. Selain kemerosotan moral dan intelektual adalah kenyataan bahwa mentalitas inderawi memusatkan perhatiannya pada kebutuhan dan keinginan materil dan jasmaniah manusia serta mendorong pemenuhan kebutuhankebutuhan ini semaksimal mungkin. ${ }^{6}$ Terkait dengan mentalitas budaya, terkait pula dengan pedoman P2KP yaitu membangun masyarakat yang mandiri dengan memperbaiki atau memberdayakan masyarakat untuk jujur, bertanggung jawab, adil dan bekerjasama untuk bersama-sama mengatasi masalah kemiskinan yang terjadi di setiap wilayahnya.

\section{P2KP (Program Penanggulangan Kemiskinan di Perkotaan)}

Menurut penjelasan dalam Manual Project Buku Satu tentang Pedoman Umum pelaksanaan P2KP menerangkan bahwa P2KP merupakan program penanggulangan kemiskinan bagi masyarakat miskin yang diakibatkan oleh krisis ekonomi dan moneter maupun bagi mereka yang secara struktural sedang mengalami kesulitan dalam menjalankan kehidupan. P2KP dikhususkan bagi masyarakat miskin di perkotaan. Selain itu P2KP adalah proyek yang mempunyai strategi dan orientasi yang lebih mengutamakan pemberdayaan masyarakat dan

\footnotetext{
${ }^{6}$ Doyle Paul Johnson, Teori Sosiologi Klasik dan Modern dalam Robert M.Z. Lawang(Ed.). Jakarta: Gramedia, 1988, hlm.106.
}

institusi lokal. ${ }^{7} \quad$ P2KP bertujuan untuk mempercepat upaya penanggulangan kemiskinan melalui:

a. penyediaan dana pinjaman bergilir untuk pengembangan kegiatan usaha produktif dan pembukaan lapangan kerja baru;

b. penyediaan dana hibah untuk membangun sarana dan prasarana dasar lingkungan;

c. peningkatan kemampuan perorangan dan keluarga miskin melalui upaya berdasarkan kemitraan dan menumbuhkan usaha-usaha kelompok;

d. penyiapan, pengembangan dan kemampuan kelembagaan masyarakat di tingkat kelurahan untuk dapat mengkoordinasikan dan memberdayakan masyarakat dalam melaksanakan program pembangunan;

e. pencegahan penurunan kualitas lingkungan melalui upaya perbaikan prasarana dan sarana dasar lingkungan. Sasaran P2KP adalah KSM (Kelompok Swadaya Masyarakat) yang terdiri dari perorangan maupun keluarga miskin yang tinggal di perkotaan. Dengan ketentuan bahwa anggota tiap-tiap KSM harus berada dari daerah yang sama yang dinaungi oleh BKM tertentu. Setiap KSM akan memperoleh bantuan dari P2KP sesuai dengan proposal yang diajukan, yaitu melalui bantuan kredit modal kerja bergulir, bantuan

\footnotetext{
7 Bappenas, Manual P2KP Buku 1: Pedoman Umum. Jakarta: Tim Persiapan P2KP, 1999, hlm.1.
} 
hibah untuk membangun atau memperbaiki sarana dan prasarana dasar lingkungan, bantuan penciptaan lapangan kerja, termasuk pelatihan.

Pengelola P2KP di tingkat kelurahan diserahkan kepada BKM setempat. BKM adalah suatu badan yang beranggotakan warga masyarakat yang diakui komitmennya pada upaya bersama menanggulangi kemiskinan, seperti perwalian kelompok wanita (PKK), Rukun Tetangga, Rukun Warga, yang mewakili warganya masing-masing ditambah perwakilan anggota KSM dan tokoh-tokoh masyarakat lainnya seperti tokoh agama, cendekiawan maupun dari LSM atau masyarakat miskin yang ditunjuk. ${ }^{8}$

Peran pokok BKM adalah menilai dan memberikan persetujuan, serta mengkoordinasi rencana-rencana kegiatan KSM, baik yang berupa kelompok usaha bersama (KUBE), maupun kelompok pengelola pembangunan prasarana dan sarana dasar lingkungan. BKM mempunyai tanggung jawab untuk merealisasikan pengelolaan dana modal bergulir di masyarakat wilayah penerima bantuan. Sebagai lembaga pimpinan kolektif masyarakat warga BKM menjadi unsur strategis dalam himpunan masyarakat setempat yang selalu peka terhadap berbagai perubahan, khususnya yang terkait dengan kemiskinan dan merumuskannya dalam bentuk kebijakankebijakan untuk dapat dilakukan oleh UP (Unit Pengelola).

\footnotetext{
${ }^{8}$ Ibid, hlm.36.
}

\section{Kinerja}

Kinerja adalah hasil kerja yang dapat dicapai oleh seseorang atau sekelompok orang dalam suatu organisasi, sesuai dengan wewenang dan tanggung jawabnya masingmasing, dalam rangka upaya mencapai tujuan organisasi bersangkutan secara legal, tidak melanggar hukum dan sesuai dengan moral dan etika. ${ }^{9}$ Sedangkan penilaian kinerja adalah suatu sistem yang digunakan untuk menilai dan mengetahui apakah seorang karyawan telah melaksanakan pekerjaannya secara keseluruhan. Yang dinilai tidak hanya hasil kerja secara fisik saja tetapi meliputi berbagai hal, seperti kemampuan kerja, disiplin, hubungan kerja, prakarsa, kepemimpinan dan hal-hal khusus sesuai dengan bidang dan level pekerjaan yang dijabatnya. ${ }^{10}$

Dalam praktiknya banyak sekali jenis metode penilaian kinerja. Masalahnya, suatu organisasi atau perusahaan harus memilih metode yang paling memberi manfaat yang besar bagi tercapainya tujuan perusahaan. Menurut Suyadi Prawirosentono ${ }^{11}$ secara umum terdapat dua (2) metode menilai kinerja karyawan, yakni.

a. Penilaian kinerja pada seseorang secara tunggal Penilaian kinerja atas seseorang secara tunggal adalah semata-mata menilai kinerja orang perorang secara

\footnotetext{
9 Suyadi Prawirosentono, Manajemen Sumber Daya Manusia:Kebijaksanaan Kinerja Karyawan. Yogyakarta: BPFE, 1999, hlm.2.

10 H.A.S.Moenir, Manajemen Pelayanan Umum Di Indonesia. Jakarta: Bumi Aksara, 2000, hlm.7.

${ }^{11}$ Suyadi Prawirosentono, op.cit., hlm. 223.
} 
individual secara individual tanpa membandingkannya dengan yang lain. Misalnya seorang pengetik dinilai secara tunggal perorangan dalam hal kecepatan dan kerapihan membuat surat bisnis. Selain itu, dinilai tentang kesalahan mengetiknya.

b. Penilaian kinerja pada sekelompok orang Penilain kinerja atas seseorang dibandingkan dengan kinerja karyawan lain disebut penilain kinerja atas kelompok. Hal ini dilakukan terutama untuk pekerjaan yang dilakukan secara kolektif atau pekerjaan seseorang yang tergantung untuk mempengaruhi kegiatan karyawan yang lain. Misalnya karyawan bagian perakitan mobil pada perusahaan perakitan kendaraan bermotor. Rangka kendaraan bermotor setelah disiapkan oleh karyawan pembuat rangka, ditempatkan pada ban berjalan untuk dilengkapi dengan body mobil oleh karyawan yang lain dan seterusnya. Jadi dalam kegiatan yang telah mempunyai diagram alur proses produksi semacam itu dituntut kinerja yang baik dari masing-masing karyawan.

Dalam penelitian ini, penulis menggunakan penilaian kinerja pada sekelompok orang. Karena yang dinilai bukanlah orang per orang namun sekelompok orang yang berkecimpung dalam organisasi yang menjadi obyek penelitian ini.

\section{Pengawasan}

Leslie W.Rue dan Lioyd L. Byars dalam Benjamin Liputo mendefinikan pengawasan sebagai berikut ${ }^{12}$ :

Suatu kegiatan untuk membandingkan kegiatan yang nyata telah dilakukan dengan standar yang telah ditentukan atau yang kemudian segera mengambil tindakan untuk mengkoreksinya setiap penyimpangan dari standar yang ada.

Menurut pendapat Djati Julitriarsa dan John Suprihanto, pengawasan mempunyai berbagi fungsi pokok, diantaranya adalah sebagai berikut. ${ }^{13}$

a. Mencegah terjadinya penyimpangan atau kesalahankesalahan; artinya bahwa pengawasan yang baik adalah suatu pengawasan yang dapat mencegah kemungkinan terjadinya berbagai penyimpangan, kesalahan, ataupun penyelewengan.

b. Untuk memperbaiki berbagai penyimpangan atau kesalahan yang terjadi; artinya bahwa adanya pengawasan haruslah dapat diusahakan cara-cara tindakan perbaikan, agar tidak berlarut-larut, yang akan mengakibatkan kerugian.

c. Untuk mendinamisir organisasi atau perusahaan serta segenap kegiatan manajemen

12 Benyamin Liputo, Pengantar Manajemen. Jakarta: Depdikbud: Dirjen Diktio P2LPTK,1988, hlm. 170 .

13 Djati Julitriarsa dan John Suprihanto, Manajemen Umun: Suatu Pengantar. Yogyakarta: BPFE, 1992, hlm.102. 
lainnya,yakni dengan adanya pengawasan diharapkan sedini mungkin dapat dicegah terjadinya penyimpangan, sehingga tujuan organisasi atau perusahaan dapat tercapai.

d. Untuk mempertebal rasa tanggung jawab, adanya pengawasan yang rutin mengakibatkan setiap bagian akan selalu bertanggung jawab terhadap semua tugas yang dilakukan.

Apabila fungsi dan tugas pengawasan tersebut dapat dilaksanakan dengan baik dan efektif maka akan sangat membantu organisasi dalam setiap proses kegiatan menuju pada pencapaian tujuan yang telah ditentukan. Pengawasan yang dilaksanakan oleh organisasi menurut Hani Handoko ${ }^{14}$ ada tipe dasar yaitu:

1) Pengawasan pendahuluan (Freed Forward Control)

Pengawasan ini dirancang untuk mengantisipasi masalahmasalah atau penyimpanganpenyimpangan dari standar atau tujuan dan memungkinkan koreksi dibuat sebelum suatu tahap kegiatan tertentu diselesaikan.

2) Pengawasan yang dilaksanakan bersamaan dengan pelaksanaan kegiatan (Concurent Control)

Pengawasan ini dilaksanakan selama kegiatan berlangsung. Tipe pengawasan ini merupakan proses dimana aspek tertentu harus dipenuhi dulu sebelum kegiatankegiatan dilanjutkan atau menjadi semacam peralatan Double Check yang lebih menjamin ketetapan pelaksanaan kegiatan.

3) Pengawasan Umpan Balik (Freeback Control)

Pengawasan ini mengukur hasil-hasil dari suatu kegiatan yang telah diselasaikan. Sebab-sebab penyimpangan dari rencana atau standar ditentukan dan penemuanpenemuan ditetapkan untuk kegiatan-kegiatan serupa dimasa yang akan datang. Pengawasan yang dilakukan oleh atasan atau berpengaruh pada tingkah laku pegawai dalam melaksanakan kegiatan atau pekerjaannya. Tidak setiap jenis kegiatan atau pekerjaan menggunakan tipe pengawasan yang sama.

\section{Pembahasan}

\section{Deskripsi Subyek Penelitian}

a. Kronologis Pembentukan BKM Pemilihan anggota BKM, bisa dilihat di gambar 1, diawali dari pemilihan utusan warga ditingkat komunitas yang warganya saling kenal, misalnya tingkat unit warga terkecil (RT). Mekanisme pemilihan utusan warga harus dilakukan dengan mekanisme tanpa kampanye, tanpa pencalonan, secara rahasia, dan tertulis, dengan proses sebagai berikut.

\footnotetext{
14 T. Hani Handoko, Manajemen, edisi 2 Yogyakarta: BPFE, 2003, hlm.362.
} 


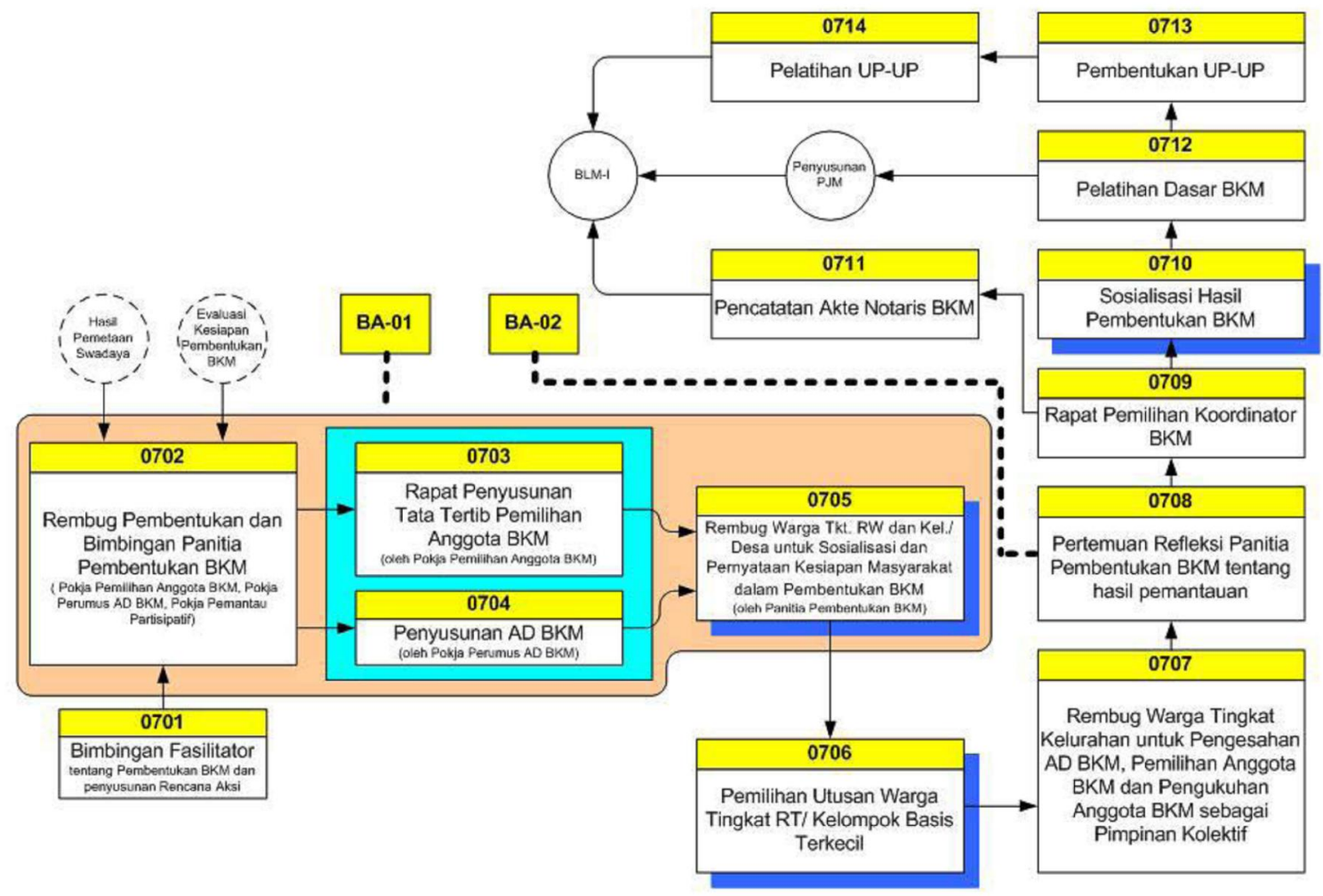

Gambar 1.

Kronologis Pembentukan BKM

1) Warga yang hadir dalam pertemuan tingkat satuan unit wilayah terkecil (RT) bersama relawan dan fasilitator melakukan FGD (Focussed Group Discussion) kepemimpinan moral.

2) Setelah FGD kepemimpinan moral, masyarakat atau warga setempat membahas dan menyepakati kriteria-kriteria utusan warga yang akan dipilih, kriteria yang dianggap paling penting dan diterima semua pihak. Kriteria yang menjadi prioritas adalah kriteria yang berkaitan dengan sifat kemanusiaan seseorang.
3) Selanjutnya atas dasar kriteria yang telah disepakati warga tersebut, Panitia pembentukan BKM mengkoordinir pelaksanaan pemilihan utusan warga di tingkat satuan unit wilayah terkecil bersangkutan.

4) Tiap pemilih (mempertimbangkan

keterlibatan wanita dan kelompok rentan) memilih 2 s/d 3 nama berbeda (sesuai kesepakatan panitia pembentukan BKM) yang dianggap masyarakat paling dapat dipercaya dan memenuhi kriteria kualitas sifat kemanusiaan, bukan hanya kewilayahan, dengan 
cara menuliskan nama-nama tersebut secara rahasia, tanpa pencalonan, tanpa kampanye atau upaya mempengaruhi untuk memilih orang tertentu.

5) Hasil-hasil pilihan warga pada saat itu pula dikumpulkan dan ditabulasikan secara terbuka di hadapan warga setempat.

6) Semua warga yang dipilih di FGD tingkat satuan unit wilayah terkecil kemudian menjadi utusan warga BKM dari pilihan warga bersangkutan. Jumlah utusan warga yang dipilih tiap satuan unit wilayah terkecil sebelumnya diputuskan oleh panitia pembentukan BKM dalam rembug warga mengenai kesepakatan merevitalisasi atau membentuk lembaga baru BKM.

7) Tiap utusan warga yang dipilih ini menjadi peserta pada saat rembug warga pemilihan anggota BKM di tingkat kelurahan.

Panitia pembentukan BKM bekerjasama dan berkoordinasi dengan Lurah atau Kepala Desa serta relawan-relawan setempat melakukan proses persiapan pelaksanaan pembentukan BKM di kelurahannya, misalnya pembuatan undangan, pengaturan tempat dan waktu, penyiapan kertas suara, dan lain-lain. Ketentuan dan mekanisme pemilihan anggota BKM dalam rembug warga tingkat kelurahan sama dengan pemilihan utusan warga, antara lain dengan mekanisme tanpa kampanye, tanpa pencalonan, secara rahasia dan tertulis.

b. Pinjaman Bergulir

Pinjaman untuk Kelompok Swadaya Masyarakat (KSM) yang membutuhkan dana untuk kegiatan yang terkait usaha produktif dari anggota-anggotanya. Batas maksimal pinjaman pertama kali bagi setiap anggota KSM adalah Rp 500 ribu. Sedangkan maksimal pinjaman untuk tahap berikutnya adalah $\operatorname{Rp} 2$ juta. Hal ini dimaksudkan sebagai proses pembelajaran masyarakat sekaligus memperkuat orientasi sasaran P2KP, yakni masyarakat miskin. Oleh karena itu, pada tahap berikutnya diharapkan KSM-KSM dan anggota-anggotanya yang telah meningkat kesejahteraannya.

Kegiatan yang menggunakan dana BLM (Bantuan Langsung Mandiri) diharapkan memberikan manfaat bukan hanya untuk perorangan saja tetapi juga sekelompok orang dengan usaha yang produktif, karena bersifat pinjaman ke KSM, maka harus dikembalikan kepada UPK. Dalam penelitian ini, dari 21 Desa di Kecamatan Adiwerna, penulis hanya mengambil data di wilayah P2KP tahap 2 yaitu 5 Desa dan hanya mengambil 4 daerah yaitu Desa Pasarean, Desa Penarukan dan Desa Tembok Luwung dan Desa Harjosari Lor.

Untuk Desa di Kecamatan Adiwerna, menurut Koordinator BKM Arum Sejahtera, Subroto mengatakan bahwa yang ikut dalam P2KP tahap 2 tahun 2003/2004 mendapat bantuan 250 juta, masingmasing $4 \%$ untuk BOP, 40 juta untuk Fisik dan Sosial (UPK dan UPS) dan 
200 juta untuk perguliran dana (UPK). Selain penulis ke lokasi tiga desa tersebut, juga mendapatkan informasi dari Fasilitator Kelurahan (Faskel) yang banyak mengetahui mengenai BKM di Kecamatan Adiwerna khususnya di daerah lokasi lama P2KP Tahap kedua (2).

\section{Pembahasan/Analisis Data}

\section{a. Penyaluran Dana BLM ekonomi bergulir P2KP oleh Badan Keswadayaan Masyarakat (BKM) di Kecamatan Adiwerna}

BKM (Badan Keswadayaan Masyarakat) dalam menjalankan kegiatannya harus menjamin bahwa semua aset serta penyaluran dana keuangan telah dilaksanakan sekretaris dan UPK secara tepat sasaran dan dapat dipertanggungjawabkan. BKM sebagai pengemban amanat di sini harus mendorong UPK agar mampu menyalurkan pinjaman bergulir sesuai dengan apa yang telah disepakati bersama.

1) Visi, misi, tujuan, prinsip dan nilai-nilai yang dijunjung P2KP tidak diterapkan secara konsisten.

Dalam menyalurkan dana P2KP yang diharapkan dapat mandiri, maju, adil, demokrasi dilapangan dalam kenyataan di lapangan tidak seperti yang diinginkan. Salah satu informan yang merupakan anggota KSM, mengungkapkan permasalahan ketidakadilan disaat akan mengajukan dana pinjaman ke BKM hanya karena suami yang terdaftar di KSM lain macet dalam mengangsur pinjaman dan itu dibenarkan oleh informan lain yang tak lain adalah salah satu anggota UPK.

Dalam kasus diatas bisa dapat dikatakan BKM masih belum adil dalam menyalurkan dana P2KP dan belum bisa memberikan solusi terbaik, misalnya ada seseorang yang tidak pernah macet mengangsur pinjaman, hanya karena suaminya macet dalam mengangsur, disaat sang istri akan pinjam lagi, tidak diberikan pinjaman, dan tidak memberikan solusi tepat untuk membantu mereka. Seperti yang dikatakan Merton, ada dis-fungsi organisasi baik itu negatif ataupun positif, dalam kasus ini, dampak negatifnya anggota KSM tidak dapat memenuhi kebutuhan sehari-hari karena tidak adanya modal, serta sedang positifnya kemungkinan membujuk suami untuk dapat mengembalikan pinjaman demi mendapatkan bantuan modal, tetapi alangkah baiknya jika BKM disini memberikan alasan kenapa mereka tidak memberikan pinjaman tersebut. Tidak harus dengan berpikir, sang suami macet jadi istripun juga kemungkinan besar macet, bila BKM mau memberikan bantuan dana, dengan sosialisasi serta solusi-solusi yang tepat misalnya dengan pemberian modal usaha diharapkan bisa membantu keluarga dan suami bisa mengangsur kembali pinjaman tersebut, kemungkinan lebih terpacu untuk berusaha keras.

2) Ditemukan penyalahgunaan penyaluran dana BLM dan BOP BKM

Penyaluran dana BLM digunakan untuk kegiatan yang secara langsung memberikan manfaat pada sebagian besar warga 
masyarakat, terutama masyarakat miskin. Informan yang merupakan anggota BKM Harjosari Lor mengakui bahwa uang yang buat alokasi ekonomi digunakan untuk menutupi anggaran pengeluaran lingkungan fisik, karena kesalahan prosedur dari BKM dan tidak adanya bantuan swadaya masyarakat.

P2KP tidak menghendaki bahwa dana BLM akan dimanfaatkan untuk hal-hal yang tidak berkaitan langsung dengan upaya penanggulangan kemiskinan, semua dana sudah ada alokasinya baik alokasi untuk lingkungan fisik, sosial atau ekonomi, disini malah uang untuk alokasi ekonomi disalahgunakan. Menunjukkan BKM kurang bijaksana dalam mengambil keputusan. Lebih baik bukankah saat untuk alokasi fisik ada dua dana, baik dana P2KP dan swadaya masyarakat, harusnya sebelum memperbaiki atau membagunbangun dari segi fisik masyarakat dimintai dana swadaya masyarakat, baru setelah semua urusan dana kelar, bisa mulai membangun disesuaikan dengan dana yang ada, dan saat memperbaiki atau membangun tidak baik menggunakan jasa pemborong apalagi itu untuk perbaikan desa, lebih baik lagi jika bersama masyarakat bergotong royong itu sehingga menimbulkan kebersamaan di dalam masyarakat tersebut, pada akhirnya tidak harus menyalahgunakan dana untuk pinjaman ekonomi bergulir untuk alokasi pembangunan lingkungan. Penyalahgunaan dana BOP (Biaya Operasional) BKM, memang terjadi di lapangan. Faskel (Fasilitator kelurahan) untuk lokasi lama P2KP mengatakan bahwa penyalahgunaan dana BOP BKM digunakan untuk diberikan kepada PJOK (Penanggungjawab Operasional Kegiatan), untuk alasan kemajuan desa.

b. Pengelolaan dana BLM ekonomi bergulir P2KP oleh Unit Pengelola Keuangan (UPK) di Kecamatan Adiwerna Unit Pengelola Keuangan adalah unit pelaksana BKM yang bertugas menjalankan keputusan serta kebijakan yang ditetapkan BKM dalam mengelola dana bergulir masyarakat dan dana lainnya. Disini UPK melakukan semua pembukuan yang sesuai dengan standar atau petunjuk P2KP, maksudnya disini adalah melakukan administrasi seluruh transaksi keuangan berbasis sistem akuntansi UPK, laporan bulanan, rekapitulasi laporan bulanan,dan laporan dipertanggungjawabkan kepada BKM, serta hasil laporan di tempel di papan pengumuman, menilai kelayakan usulan warga/KSM berdasarkan pada kelayakan usaha, yang kemudian diverifikasi oleh anggota BKM, pencairan kredit, pembayaran kembali kredit, menagih secara pro aktif terhadap KSM sesuai jadwal. Improvisasi scenario penagihan yang luwes bagi yang tidak setor.

Dalam observasi di lapangan penulis hanya melihat dua UPKBKM yang menempelkan laporan keuangan di lima papan pengumuman tempat strategis, sedang yang lainnya hanya di satu atau dua papan pengumuman. Sebagai UPK yang salah satunya 
bertugas menilai kelayakan usulan warga atau KSM berdasarkan pada kelayakan usaha, yang kemudian diverifikasi oleh anggota BKM, prosesnya KSM membuat proposal atau mengisi formulir pengajuan dana untuk usaha yang diberikan oleh UPK dibantu UPK mengisi, bila dianggap layak mendapat dana kemudian diverifikasi ke BKM. Bila mendapatkan pinjaman, semua anggota KSM yang mendapatkan pinjaman diberikan sosialisasi mengenai pinjaman dan syarat-syarat ke depannya, tahap pencairan pinjaman didampingi BKM dan disaksikan seluruh anggota KSM yang mendapatkan dana tersebut. pembayaran kembali pinjaman, ada yang harus ditagih dari rumah ke rumah oleh UPK-BKM, ada pula yang datang sendiri ke kantor BKM.

Hambatan dalam menjalani tugas sebagai UPK adalah kemacetan yang sangat besar karena faktor dari usaha KSM tersebut, kurang sosialisasi karena dana yang dipinjam dikira dana hibah, dan banyak faktor tersendat di Ketua KSM ataupun dari anggota KSM. Mengelola dana bergulir jadi pikiran cuma KSM dapat mengembalikan pinjaman "Sregep ngangsur", sehingga tidak ada proses belajar, tidak ada transfer ilmu untuk berpikir bagaimana caranya agar tidak terjadi kemacetan tetapi tidak salah sasaran. Terjadi penyelewengan dana disebabkan karena ketidaktahuan masyarakat atau tahu tapi tidak mau tahu sehinggga dengan sengaja atau tidak disadari akhirnya dana beralih fungsi, dan tidak ada tindak lanjut dari UPK maupun BKM. BKM tidak hanya memberikan kelayakan KSM-KSM yang mendapat dana pinjaman tetapi juga mengerti kenyataan dilapangan, mensosialisasi bantuan bukan hibah namun pinjaman, kebenaran usaha yang dilakukan KSM, mengerti hambatan usaha KSM, diskusi dengan KSM, berpikir kreatif dengan bekerjasama dengan pihak luar yang bisa diajak bekerjasama demi kemajuan desa.

\section{c. Penggunaan dana BLM ekonomi bergulir P2KP oleh Kelompok Swadaya Masyarakat (KSM) di Kecamatan Adiwerna}

Kelompok Swadaya Masyarakat adalah kelompok yang terdiri dari perorangan maupun keluarga miskin yang tinggal di perkotaan. Dengan ketentuan bahwa anggota tiap-tiap KSM harus berada dari daerah yang sama yang dianungi oleh BKM tertentu. Setiap KSM akan memperoleh bantuan dari P2KP sesuai dengan proposal yang diajukan, yaitu melalui bantuan kredit modal kerja bergulir untuk mewujudkan masyarakat mandiri dalam menanggulangi kemiskinan. Dari beberapa informan, diketahui bahwa syarat KSM ekonomi bergulir, antara lain:

1) KSM punya tujuan, penciptaan usaha dan peningkatan pendapatan

2) KSM sukarela, demokratis, transparan, akuntabilitas dan kesetaraan masing-masing anggota.

3) Paling tidak $2 / 3 \quad \mathrm{KSM}$ masyarakat yang miskin sesuai kriteria BKM 
4) Semua anggota menyetujui aturan-aturan KSM

5) Pengurus KSM dipilih demokratis

6) Adanya jadwal pertemuan teratur guna menyusun kegiatan pelaksanaan

7) Ikatan persaudaraan kuat

8) Administrasi keuangan sederhana

9) Tahu sistem tanggung renteng15 dalam tulisan

Kriteria anggota KSM adalah termasuk dalam masyarakat kurang mampu (miskin), memenuhi kriteria yang disepakati kelompok, dapat dipercaya dan bekerjasama, sanggup menabung secara teratur sesuai kemampuan atas nama kelompok KSM maupun pribadi, hadir dan berpartisipasi dalam pertemuan anggota KSM, mengenai rencana ekonomi Rumah Tangga mengenai peluang usaha mikro dan kebutuhan akan kredit guna mengembangkan usahanya, memiliki motivasi untuk berusaha dan bekerja, memerlukan tambahan modal untuk usahanya tahap pertama (1) Rp 500.000,00 dan max tidak lebih dari Rp 2.000.000,00.

Karakter "Sregep ngangsur", secara logika mampu mengembalikan dana tersebut, maka bisa diajukan terus dan digulirkan, Jika KSM yang disetujui karena angsuran baik meskipun sangat melenceng dan tidak tepat sasaran

\footnotetext{
15 Sistem tanggung renteng adalah dimana anggota KSM punya tabungan bersama, jika salah satu anggota KSM tidak bisa atau kurang dalam membayar pinjamannya pada UPK-BKM, akan dibantu oleh anggota KSM yang lain, dan bantuan dari sesama anggota KSM itu kemudian akan menjadi hutang individu anggota KSM tersebut,sesuai kesepakatan tiap KSM.
}

sesuai dengan yang telah disepakati dalam aturan BKM. Salah satu informan mengatakan bahwa uang yang disetorkan lewat ketua KSM kadang tidak sampai di UPK, dan informan lain mengakui memakai uang yang disetorkan anggotanya untuk kebutuhan sehari-hari, sedang faktor lainnya adalah anggota KSM yang memang macet disebabkan karena memang usahanya yang pasang surut, dan untuk membeli kebutuhan sehari-hari serta adanya faktor dari luar yang memprovokasi kalau pinjaman itu tidak dikembalikan tidak apa-apa.

Semua penyelewengan yang terjadi di KSM sebenarnya diketahui oleh BKM, baik itu macet di ketua KSM, anggota KSM, dan yang lainnya. Namun BKM tetap diam karena tuntutan dari program P2KP yaitu dana dikelola UPK dan diharapkan terus berputar. Pada awalnya BKM memberikan dana pada miskin produktif tetapi malah jadi konsumtif, dan tidak dapat mengembalikan, Sehingga BKM untuk menghentikan yang macet, BKM cuma berorientasi pada yang bisa mengembalikan dana. Ini merugikan KSM atau masyarakat miskin yang benar-benar produktif sehingga tidak mendapat akses untuk dapat dana, sehingga disini tidak ada proses belajar bagi masyarakat miskin seperti tujuan P2KP. Perlu adanya perbaikan mentalisme dari masyarakat sendiri untuk lebih jujur, bertanggung jawab, bekerjasama, tidak hanya berorientasi pada kebutuhan konsumtif saja. 
d. Kinerja BKM dalam pengawasan penggunaan dan pengelolaan dana BLM ekonomi bergulir P2KP di Kecamatan Adiwerna

Melihat BKM dalam mengawasi pengelolaan dan penggunaan dana BLM ekonomi bergulir. Bagaimana BKM dikatakan lembaga yang kinerjanya efektif dalam melakukan pengawasan penggunaan dan pengelolaaan dana P2KP.

- Memilih dan menentukan masyarakat yang berhak menggunakan dan mendapatkan dana P2KP

Terkait bagaimana program ini dilaksanakan, bagaimana mendorong keterlibatan masyarakat miskin dan musyawarah bersama komponen masyarakat lain dalam memanfaatkan akses peluang yang ada di P2KP untuk penanggulangan kemiskinan. Menurut informan fokus yang terpenting adalah mengatasi kredit macet, dengan ditagih ke setiap KSM oleh UPK dan dana yang terus berputar minimal diberikan kepada mereka yang bisa mengembalikan pinjaman walau itu bukan kepada masyarakat miskin. Melihat kondisi diatas, terlihat tidak ada transformasi pengalaman, ketrampilan dan sikap yang baik dalam mengatasi permasalahan kemiskinan. UPK-BKM hanya mengejar untuk berlanjutnya program, tidak lagi berpedoman pada prinsip, visi, misi dan program P2KP

- Pengelolaan dana pinjaman bergulir UPK-BKM

Temuan yang didapat di lapangan adalah kemacetan yang besar di tiap KSM, baik itu faktor dari intern KSM (kemacetan yang terjadi karena disalahgunakan oleh anggota KSM, Ketua KSM) ataupun faktor dari luar yaitu provokasi dana pinjaman adalah hibah, dampak kebijaksanaan pemerintah ataupun krisis ekonomi, serta kurang pengawasan dari BKMUPK sendiri. Selain itu, kurang kerjasama antara masyarakat, pihak kelurahan dan kecamatan untuk berpartisipasi aktif dalam penanggulangan kemiskinan di tiap desa atau bisa dikatakan kebersamaan seluruh anggota masyarakat dalam upaya menanggulangi kemiskinan di sekitar belum ada, sehingga terkesan BKM adalah organisasi yang berdiri sendiri di setiap desa.

- Pelaksanaan penggunaan dan pengelolaan dana ekonomi bergulir

Dalam kegiatan BKM-UPK baik mengelola atau menggunakan dana ekonomi bergulir atau pinjaman bergulir memerlukan sosialisasi yang matang kepada seluruh anggota masyarakat. Sosialisasi yang dilakukan BKM, baik dengan perbaikan mental masyarakat, perbaikan dan pendekatan melalui jalur-jalur religi. Membawa dampak buruk bagi upaya pengentasan kemiskinan akibat dari perilaku masyarakat dan pelaku pembangunan yang kurang memiliki moralitas dan keberanian untuk mengatasi kemiskinan.

a) Tidak terjadi perubahan perilaku secara kolektif dari semua pihak sesuai dengan nilai-nilai P2KP.

Beberapa indikatornya antara

lain: 
- Kemiskinan bukan tanggung jawab bersama tetapi tanggung jawab individu dalam kelompok

- Peran BKM bukan sebagai pengawas dan kontrol sebagaimana mestinya dalam aturan P2KP

- Paradigma pemerintah lokal bertumpu pada potensi serta kemandirian yang dimiliki dan mengurangi mental ketergantungan dari luar tidak dapat terwujud dan belum menunjukkan tanda-tanda ke arah tersebut

b) Tidak terjadi kemitraan Sinergis KSM-UPK-BKM dalam program $\mathrm{P} 2 \mathrm{KP}$.

Dalam BKM sendiri, tidak ada kemitraan kepada masyarakat miskin. Tidak ada kerjasama yang baik antara UPK-BKM dengan masyarakat miskin yang menjadi sasaran program, sehingga program berjalan tapi di sisi lain kehilangan jiwa dan tujuan awal dari adanya lembaga tersebut. Lagi-lagi masalah kemiskinan sangat jauh di atasi, sudah terlupakan, dilupakan dan menjadi hal yang tak perlu dilihat dan dipedulikan lagi. Padahal keberadaan serta kinerja kader masyarakat sangat diperlukan, sangat strategis dan vital.

c) Lemahnya pemahaman pengurus BKM fungsi dan peran mereka sebagai agen perubah dan pemberdayaan masyarakat.

BKM yang bertindak sebagai motor penggerak agar terdapat partisipasi aktif dari masyarakat sekitar untuk menganggulangi kemiskinan, disini BKM melakukan pengawasan dengan melihat pembukuan tiap bulannya, melihat angsuran yang jatuh tempo, agar UPK menagih ke KSM-KSM. Memperbaiki kemiskinan dengan bantuan dan bimbingan dari BKM, dalam pelaksanaan justru tidak dapat mengakses dana P2KP tersebut dikarenakan harus mengembalikan/mengangsur dana pinjaman tersebut sehingga dipakai yang ekonomi atas. Diperlukan partisipasi aktif dan krisis sebagai bangsa yang integral, untuk lebih bertanggung jawab, dan mandiri menyelesaikan permasalahan. Perubahan perilaku dan peningkatan kapasitas hanya bisa tercapai bila diawali dengan proses penyadaran masyarakat mengenai substansi dari kegiatan pengelolaan dana, jadi paham apa, mengapa, untuk apa dan bagaimana kegiatan dilakukan.

\section{Pokok-Pokok Temuan Penelitian}

1. Lemahnya pemahaman pengurus BKM fungsi dan peran mereka sebagai agen perubah dan pemberdayaan masyarakat.

2. Tidak terjadi perubahan perilaku secara kolektif dari semua pihak sesuai dengan nilai-nilai P2KP

3. Ditemukan penyalahgunaan penyaluran dana BLM dan BOP BKM

4. Kemacetan dana BLM ekonomi bergulir yang sangat besar, karena factor intern dan faktor intern.

5. Tidak terjadi kemitraan sinergis KSM-UPK-BKM dalam program $\mathrm{P} 2 \mathrm{KP}$

6. Tidak adanya kepercayaan dan kerjasama antara seluruh 
komponen masyarakat untuk bersama menanggulangi kemiskinan.

\section{E. Kesimpulan}

Program P2KP berorientasi pada pemberdayaan masyarakat mandiri atau bersama membangun kemandirian, dengan terwujudnya kelembagaan masyarakat lokal mandiri, yakni Badan Keswadayaan Masyarakat (BKM). Lembaga masyarakat ini dipercaya sebagai pengelola dana Bantuan Langsung Mandiri (BLM) dan sebagai pemeduli terhadap kemiskinan di komunitasnya. Setelah melakukan analisis data mengenai kinerja BKM dalam pengawasan pengelolaan dan penggunaan dana BLM ekonomi bergulir P2KP di Kecamatan Adiwerna, diperoleh beberapa kesimpulan berikut ini:

1. Dalam penyaluran dana BLM ekonomi bergulir P2KP oleh Badan Keswadayaan Masyarakat (BKM) di Kecamatan Adiwerna

a. Visi, misi, tujuan, prinsip dan nilai-nilai yang dijunjung P2KP tidak diterapkan secara konsisten.

b. Ditemukan penyalahgunaan penyaluran dana BLM dan BOP BKM

2. Dalam pengelolaan dana BLM ekonomi bergulir P2KP oleh Unit Pengelola Keuangan (UPK) di Kecamatan Adiwerna, banyak hambatan dalam menjalani tugas sebagai UPK adalah kemacetan yang sangat besar karena faktor dari usaha KSM tersebut, kurang sosialisasi karena dana yang dipinjam dikira dana hibah, dan banyak faktor tersendat di Ketua KSM ataupun dari anggota KSM.

3. Penggunaan dana BLM ekonomi bergulir P2KP oleh Kelompok Swadaya Masyarakat (KSM) di Kecamatan Adiwerna sebagian besar digunakan untuk modal usaha, dan juga terkadang untuk konsumtif atau kebutuhan lain selain untuk modal usaha.

4. Kinerja BKM dalam pengawasan pengelolaan dan penggunaan dana BLM ekonomi bergulir P2KP di Kecamatan Adiwerna belum bisa efektif dalam kinerjanya secara kelembagaan, karena:

a. Tidak terjadi perubahan perilaku secara kolektif dari semua pihak sesuai dengan nilai-nilai P2KP

b. Tidak terjadi kemitraan Sinergis KSM-UPK-BKM dalam program $\mathrm{P} 2 \mathrm{KP}$

c. Lemahnya pemahaman pengurus BKM fungsi dan peran mereka sebagai agen perubah dan pemberdayaan masyarakat.

d. Paradigma pemerintah lokal bertumpu pada potensi serta kemandirian yang dimiliki dan mengurangi mental ketergantungan dari luar tidak dapat terwujud dan belum menunjukkan tanda-tanda ke arah tersebut.

e. Penyaluran dana kurang tepat sasaran

f. Belum mampu memberikan kontribusi

untuk 
| Puji Rahayu

meyelesaikan persoalan Lawang(Ed.). Jakarta: Gramedia, kemiskinan sifat multi 1988.

dimensional dan struktural.

\section{Daftar Pustaka}

Alimadan, Sosiologi Ilmu Pengetahuan Berparadigma Ganda. Jakarta: Rajawali Pers,1992.

Bappenas, Manual P2KP Buku 1: Pedoman Umum. Jakarta: Tim Persiapan P2KP, 1999.

Benyamin Liputo, Pengantar Manajemen. Jakarta: Depdikbud: Dirjen Diktio P2LPTK,1988.

Djati Julitriarsa dan John Suprihanto, Manajemen Umun: Suatu Pengantar. Yogyakarta: BPFE, 1992.

Doyle Paul Johnson, Teori Sosiologi Klasik dan Modern dalam Robert M.Z.
H.A.S.Moenir, Manajemen Pelayanan Umum Di Indonesia. Jakarta: Bumi Aksara, 2000

Parsudi Suparlan, Kemiskinan di Perkotaan. Jakarta: Yayasan Obor Indonesia, 1993.

Soerjono Soekanto, Teori Sosiologi tentang Pribadi dalam Masyarakat. Jakarta: Ghalia Indonesia, 1982.

Suyadi Prawirosentono, Manajemen Sumber Daya Manusia:Kebijaksanaan Kinerja Karyawan. Yogyakarta: BPFE, 1999.

T. Hani Handoko, Manajemen, edisi 2. Yogyakarta: BPFE, 2003. 